\title{
Influence of stocking density and type of feed on the rearing of crucian carp, Carassius carassius (L.), larvae under controlled conditions
}

\author{
Daniel Żarski • Katarzyna Targońska • Sławomir Krejszeff • \\ Maciej Kwiatkowski • Krzysztof Kupren • Dariusz Kucharczyk
}

Received: 20 October 2010/Accepted: 11 February 2011/Published online: 1 March 2011

(C) The Author(s) 2011. This article is published with open access at Springerlink.com

\begin{abstract}
Two experiments were conducted into the rearing of crucian carp larvae under controlled conditions in an experimental closed water system. In both cases, the rearing lasted 21 days. The first experiment concerned the initial stocking density (from 50 to 600 individuals per 1), whilst the second one studied the first food offered (two types of Artemia nauplii, decapsulated Artemia cysts and three types of commercial feeds) which were applied at the moment of exogenous feeding commencement. The best results were obtained using 50 larvae per 1, whilst there were no significant differences within the range 200-600 larvae per 1 . The application of dry feed had a negative influence on the survival and other parameters. The highest survival rate was found in the groups fed with freshly hatched Artemia naupli. The results obtained indicate that the rearing of crucian carp larvae may be successfully conducted in very high stocking densities. However, the very high sensitivity of crucian carp larvae to the type of food offered during the initial days of life should be taken into account. The data presented in this article could be very useful in crucian carp larviculture.
\end{abstract}

Keywords Crucian carp - Larviculture - Stocking density · First feeding · Controlled rearing

\section{Introduction}

Until recently, it was believed that the common presence of crucian carp, Carassius carassius (L.), in various, sometimes extremely differing, types of water reservoirs offered a risk-free future for the species. This was related, amongst others, to its low sensitivity to periodic oxygen deficits and the ability to adapt to unfavourable environ-

D. Żarski $(\bowtie) \cdot$ K. Targońska · S. Krejszeff · M. Kwiatkowski · K. Kupren · D. Kucharczyk Department of Lake and River Fisheries, University of Warmia and Mazury in Olsztyn, Oczapowskiego 5, pok. 325, 10-957 Olsztyn, Poland e-mail: danielzarski@interia.pl 
mental conditions (Holopainen et al. 1997). However, the abundance of many populations shows a decreasing trend over almost the entire area of its natural occurrence (Skrzypczak and Mamcarz 2005; Tarkan et al. 2009). On the other hand, the production of crucian carp in Asian countries reached over 1.9 million tons in 2007 whilst the total production value exceeded 1.6 billion dollars (FAO statistics-ftp://ftp.fao.org/fi/ stat/summary/a-6.pdf), which positions it in the top ten of aquaculture production. In the majority of cases, production is conducted extensively in earthen ponds (FAO 2004). For decades, crucian carp has been one of the most important species in fresh waters in Central Europe (Skrzypczak and Mamcarz 2005). For many years, this species (due to its flexibility) has been the subject of many scientific studies (e.g. Skrzypczak and Mamcarz 2005; Copp et al. 2008; Tarkan et al. 2009). However, data on the biological aspects of rearing the larvae of this species under controlled conditions as stocking material is fragmentary.

Sustainable aquaculture plays a very important role in the active protection of endangered fish species (Sarkar et al. 2006; Ross et al. 2008), and the rearing of the larvae under controlled conditions is one of the most effective methods for production of stocking material for restitution purposes (Shiri Harzevili et al. 2003, Sarkar et al. 2006; Hamáčková et al. 2009). This relates to both economic profitability of production (Kupren et al. 2008; Hakuć-Błażowska et al. 2009) and effectiveness of restitution operations, which depend directly on releasing material of an appropriate size and quality and at the appropriate time to the environment (Cowx 1994).

Studies on the controlled rearing of the larvae allow an objective and precise determination of the conditions necessary for appropriate growth resulting from the biological conditions of a given species. Factors such as feed type and stocking density have a direct influence on the rearing effects (Wolnicki 2005; Żarski et al. 2008) and may differ significantly between different species (Wolnicki 2005; Kujawa 2004; Sarkar et al. 2006; Żarski et al. 2008). The application of dry feed decreases the rearing costs significantly and allows more rational and time-effective feeding. Larvae of some fresh water fish species, such as the barbel Barbus barbus (L.), nase Chondrostoma nasus (L.) or rudd Scardinius erythrophthalmus (L.), can be fed compound feed from the first day without any major influence on their survival (Kujawa 2004; Wolnicki 2005; Wolnicki et al. 2009). But the other freshwater species, such as ide Leuciscus idus (L.), chub Leuciscus cephalus (L.) or asp Aspius aspius (L.), need to ingest exogenous digestive enzymes with live prey (Dạbrowski 1984a, b; Kujawa 2004; Wolnicki 2005). The application of high stocking densities may positively affect production costs (King et al. 2000; Kupren et al. 2008). Many studies have covered densities from several tens to a maximum of 200 larvae per 11 (King et al. 2000; Kujawa 2004; Fréchette 2005; Żarski et al. 2008; Kupren et al. 2009). In those studies, the decrements in growth rate and survival rates were found to be highly dependent on the stocking density (e.g. Alvarez-Gonzalez et al. 2001; Kujawa 2004; Żarski et al. 2008). Preliminary studies indicate that the rearing of cyprinid fish larvae at densities reaching 400 individuals per 1 without a negative effect on their survival and condition is possible (Kupren et al. 2009). The above-mentioned variability amongst freshwater fish species creates the necessity of determining the optimum rearing conditions for each individual species.

The aim of the study was to investigate the growth rate and survival of crucian carp larvae reared at different stocking densities and fed solely with different diets. 


\section{Materials and methods}

\section{Stock management and rearing conditions}

The material for the experiments consisted of crucian carp larvae obtained from controlled reproduction according to the methodology described by Targońska et al. (2009). Crucian carp spawners were caught from Sasek Wielki Lake (north-eastern Poland) and transported to the hatchery of the Department of Lake and River Fisheries, Warmia and Mazury University in Olsztyn, where they were placed in 1,000 1 tanks equipped with the possibility of controlling the environmental conditions (Kujawa et al. 1999). The initial water temperature was $16^{\circ} \mathrm{C}$ and over 2 days was gradually increased to the $19^{\circ} \mathrm{C}$ and hormonal stimulation was then applied. The fish of both sexes were treated with Ovopel, which is a commercial preparation containing a mammalian analogue of LH-RH [(D$\mathrm{Ala}^{6}, \mathrm{Pro}^{9}$-Net)-mLH-RH] and dopamine antagonist-metoclopramide (one Ovopel pellet contains $18-20 \mu \mathrm{g}$ of LH-RHa and 8-10 mg of metoclopramide) (Horvath et al. 1997) in two doses of 0.2 and 1.0 pellet per $1 \mathrm{~kg}$ of the spawner's body weight, respectively. The time between injections was $12 \mathrm{~h}$. After the first injection, the water temperature was increased to $20^{\circ} \mathrm{C}$ and to $21^{\circ} \mathrm{C}$ after the second injection. The gametes were obtained $16 \mathrm{~h}$ after the second injection. Fertilised eggs (obtained from six females) were incubated in Weiss jars in water at $21^{\circ} \mathrm{C}$. The larvae hatched after 3 days. They were then transferred to the collective tank (total volume $150 \mathrm{l}$ ) and placed in a closed water system. Next, the water in the tank was gradually raised to $25^{\circ} \mathrm{C}$. Three days post-hatch (DPH) larvae started active swimming.

The study was divided into two separate experiments during which the same rearing conditions were maintained. The rearing was conducted in closed freshwater circuits with automatic controls for temperature, photoperiod and additional aeration of water. For each experiment, actively swimming larvae with filled posterior chambers of the swim bladder were used (4 DPH). The fish were not fed until that moment. The water temperature during the rearing was constant at $25^{\circ} \mathrm{C}( \pm 0.1)$. This temperature was found to be optimal for cyprinid larvae (Wolnicki 2005). The tanks were illuminated with white fluorescent light and the photoperiod was $12 \mathrm{~h}$ (12L:12D). The larvae were fed three times a day. The first feeding was conducted an hour after switching on the light and the next two at $5 \mathrm{~h}$ intervals. The rearing tanks were cleaned twice a day (before the first and the last feeding). At that time, dead individuals were removed and their numbers were recorded. The content of ammonia and nitrites was checked daily using an LF205 photometer (Slandi, Poland) and its level did not exceed 0.1 and $0.05 \mathrm{mg} \mathrm{l}^{-1}$, respectively. In addition, the content of oxygen dissolved in the water in rearing tanks was checked using a digital oxygen meter (HI 91410, Hanna Instruments, Italy). The oxygen level did not drop below $80 \%$ saturation during 21 days of rearing.

Control measurements, during which the total length of the larvae was measured $( \pm 0.1 \mathrm{~mm})$, were conducted on the first day of the experiment and in subsequent 7-day intervals. The individual average weight $( \pm 0.1 \mathrm{mg})$ was determined at the beginning and the end of each experiment. To perform the measurement, 30 individuals were sampled from each experimental treatment and anaesthetized in 2-phenoxyethanol (Sigma-Aldrich, Germany) $\left(0.4 \mathrm{ml} \mathrm{l}^{-1}\right)$. The larvae were photographed and measurements were done using ProgRes ${ }^{\circledR}$ Capture Pro 2.5 computer software (Jenoptik, Germany). After measurement, the fish were returned to the same tanks from which they had been taken. 
Experiment 1: stocking density

The rearing was carried out in glass, cubic-shaped 11 capacity tanks where part of one wall of each rearing tank was replaced with a $0.2 \mathrm{~mm}$ mesh net, which prevented the fish and food from escaping the tank. The tanks were placed in a larger glass tank (total capacity 50 1) that formed the water bath and were supplied through the top water inlet after mechanical and biological filtration. This experimental unit, especially designed for this purpose, ensured water quality and other environmental rearing conditions at the same level independently of density and replication (described in detail in Krejszeff et al. 2010). Mechanical and biological filtration was provided with an external filter (Fluval 405). The water flow was the same in each rearing tank, gradually increased during the rearing from 100 to $150 \mathrm{ml} \mathrm{min}^{-1}$. The stocking densities were: 50, 100, 200, 300, 400, 500 and 600 individuals per 1 . The experimental groups were marked as Cc-50, Cc-100, Cc-200, Cc300, Cc-400, Cc-500 and Cc-600, respectively. The larvae were fed with freshly hatched Artemia naupli (Artemia sp.). The food was supplied proportionally to the initial stocking density and fish growth. The larvae were fed according to their density. Initially (day 1), the daily feed for the larvae was 300 nauplii per capita and was given in three equal portions. The feed dose was increased daily by $5 \%$. The experiment was conducted in three replications.

\section{Experiment 2: different diet}

The rearing was carried out in 1.51 capacity tanks of the same design as in experiment 1. The closed water system was much larger with a relatively large total capacity (500 1). The mechanical and biological filtration systems were also greater and more effective in preventing accumulation of nitrogen compounds in the system, which could be observed where different (high-protein) food was offered. The larvae density was 100 individuals per 1 1. Six experimental groups were set, each fed on a different feed: Artemia nauplii (group AN), Artemia nauplii incubated with continuous Vibrio suppression compound (Artemia High 5, group AH), Gemma Micro feed (group GF), Perla feed (group PF), Hikari feed (group HF) and decapsulated Artemia cysts (group DC). The applied dry diets were the most commonly used commercial starter feeds in freshwater larviculture. Each of the feeds was recommended as sufficient diets for fish larvae as a sole food due to its stability in water and long-term suspension in the water column. Pellets of each of the feeds were smaller than Artemia nauplii. The feed characteristics are presented in Table 1. Feeding was performed manually (always slightly excessive) in such a way that food was available for the larvae for $1 \mathrm{~h}$. Each experimental treatment was performed in triplicate.

\section{Data analysis and statistics}

The specific growth rate (SGR, $\left.\% \mathrm{~d}^{-1}\right)$ was computed according to the formula $\left(\ln W_{T^{-}}\right.$ $\left.\left.\ln W_{t}\right) 100\right)(T-t)^{-1}$, where $W_{t}$ and $W_{T}$ represent the weight of fish at the beginning (day 0 ) and the end (day 21) of rearing and $T-t$ represent the number of days between measurements (Jørgensen and Jobling 1993). On the last day of each experiment, Fulton's condition coefficient $(K)$ was computed according to the formula: $K=100 \mathrm{~W} \mathrm{TL}^{-3}$, where W means bodyweight $(\mathrm{mg})$, and TL the total length of larvae $(\mathrm{mm})$. The larval development stage (LDS) for each experimental treatment according to the scale proposed for carp by Penaz et al. (1983) (LDS 1-6) was also determined. An additional stage (7) was 
Table 1 Composition (\%) of food, used in controlled initial rearing of crucian carp larvae-producers description

\begin{tabular}{|c|c|c|c|c|c|c|}
\hline $\begin{array}{l}\text { Kind of food } \\
\text { (group) } \\
\text { Producer }\end{array}$ & $\begin{array}{l}\text { Artemia } \\
\text { nauplii (AN) } \\
\text { Aquaculture } \\
\text { International, } \\
\text { USA }\end{array}$ & $\begin{array}{l}\text { Artemia high } 5 \\
\text { (AH) } \\
\text { Inve } \\
\text { Aquaculture, } \\
\text { USA }\end{array}$ & $\begin{array}{l}\text { Decapsulated } \\
\text { cysts (DC) } \\
\text { Inve } \\
\text { Aquaculture, } \\
\text { USA }\end{array}$ & $\begin{array}{l}\text { Gemma } \\
150(\mathrm{GF}) \\
\text { Skretting, } \\
\text { Norway }\end{array}$ & $\begin{array}{l}\text { Hikari } \\
\text { plankton (HF) } \\
\text { Kyorin, Japan }\end{array}$ & $\begin{array}{l}\text { Perla } \\
\text { larva (PF) } \\
\text { Skretting, } \\
\text { Norway }\end{array}$ \\
\hline Protein & 42 & 42 & 54 & 55 & 48 & 62 \\
\hline Fat & 20 & 20 & 9 & 15 & 3 & 11 \\
\hline Carbohydrates & $11-23$ & $11-23$ & nd & nd & nd & nd \\
\hline Fibre & nd & nd & 6 & 5 & 2 & 0.8 \\
\hline Ash & nd & nd & 4 & 13.5 & 18 & 10 \\
\hline Phosphorus & nd & nd & nd & 2 & 1.3 & 1.1 \\
\hline $\begin{array}{l}\text { Additional } \\
\text { data }\end{array}$ & $\begin{array}{l}85 \% \text { hatching } \\
\text { rate }\end{array}$ & $\begin{array}{l}85 \% \text { hatching } \\
\text { rate; } \\
\text { Continuous } \\
\text { Vibrio } \\
\text { suppression }\end{array}$ & - & $\begin{array}{l}\text { Contains } \\
\text { vitamin } \mathrm{A} \text {, } \\
\mathrm{D}_{3}, \mathrm{E}\end{array}$ & $\begin{array}{l}\text { Contains } \\
\text { vitamin } \mathrm{A} \text {, } \\
\mathrm{C}, \mathrm{D}_{3}, \mathrm{E}\end{array}$ & - \\
\hline
\end{tabular}

nd no data

introduced for individuals without the fin fold. Final biomass (mean individual weight $\times$ final number of larvae) was calculated for stocking density experiment.

The statistical analysis of the data was carried out using the STATISTICA for Windows ver. 8.0 PL software package (StatSoft). All of the values expressed as percentages were arcsine-transformed prior to statistical analysis. The differences between groups regarding larval length, weight, survival and SGR were analysed with a one-way analysis of variance (ANOVA), because only one independent variable (factor) from experiments 1 and 2 was tested. When ANOVA showed significant differences, Tukey's post hoc test $(\alpha=0.05)$ was applied. The comparison of the developmental stages and Fulton's coefficient between experimental groups was performed using a non-parametric Kruskall-Wallis test $(\alpha=0.05)$. Analysis of regression was performed between the final biomass and stocking density using MS Excel for Windows.

\section{Results}

\section{Experiment 1}

Statistically significant differences in larvae length were recorded on the 14th day of rearing. Individuals in groups Cc-50 and Cc-100 were significantly longer than the larvae from the other groups and achieved an average total length of 14.19 and $14.24 \mathrm{~mm}$, respectively (Table 2). Between the other groups, no differences in the total length of the larvae were found and the results ranged from 11.84 to $12.63 \mathrm{~mm}$, respectively in groups Cc-600 and Cc-200. On the last day of the experiment, the statistically largest average total length was recorded for the larvae from the lowest stocking density (group Cc-50), where they reached an average of $17.77 \mathrm{~mm}$. The larvae from a stocking density of 100 individuals per 1 were significantly smaller (average $16.70 \mathrm{~mm}$ ) than $\mathrm{Cc}-50$, but significantly longer than the fish from the remaining groups (except for group Cc-300). No significant 


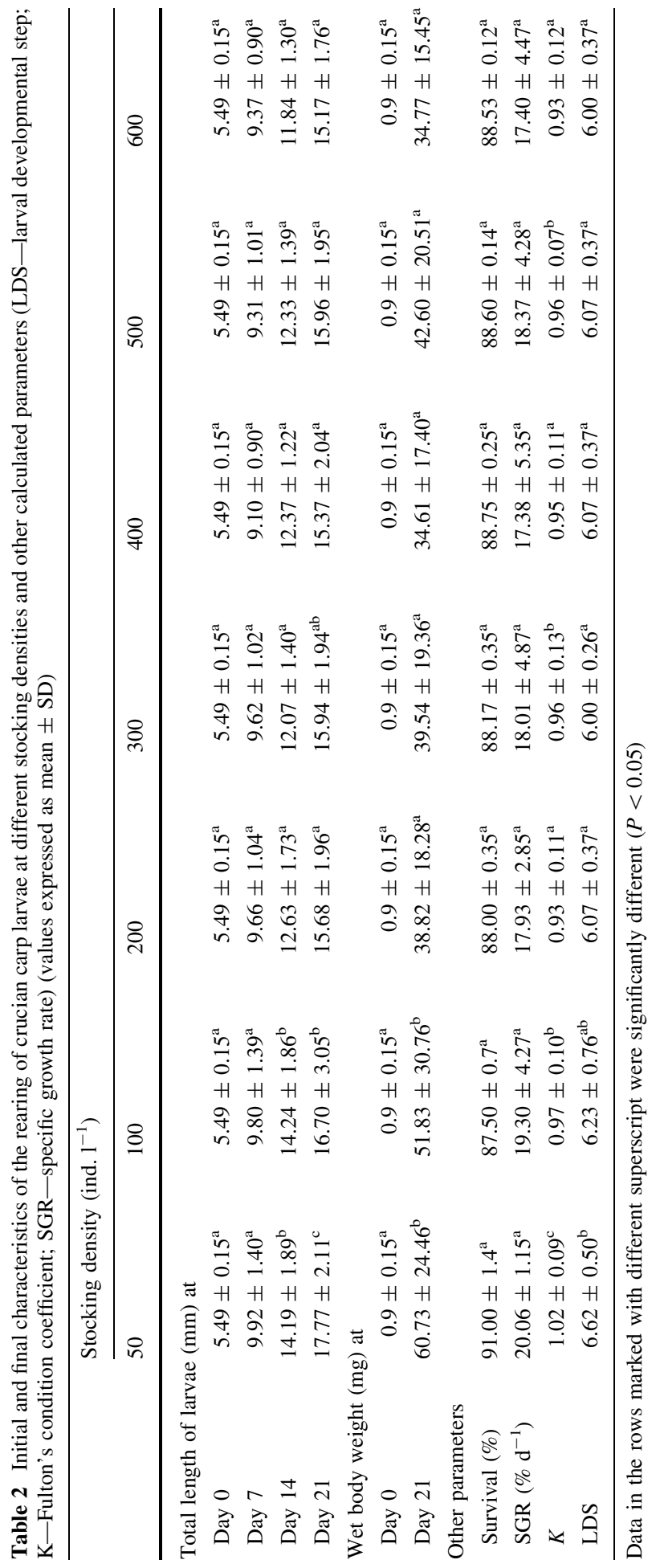




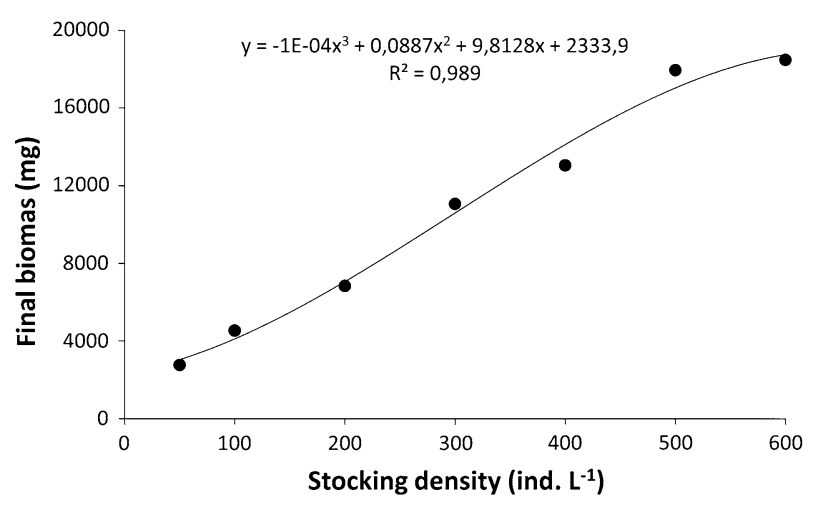

Fig. 1 Correlation between the stocking density and the mean fish biomass obtained after 21 days of controlled rearing of crucian carp larvae at different stocking densities

differences were found amongst groups from Cc-200 to Cc-600. As concerns the average weight at the end of the experiment, no significant differences were recorded between groups Cc-200 and Cc-600 (the range of average values from 34.61 to $42.60 \mathrm{mg}$ ) which, in turn, were significantly smaller than individuals in groups Cc-50 and Cc-100 (with the average values of 60.73 and $51.83 \mathrm{mg}$, respectively) (Table 2). The final biomass obtained was the largest in Cc-600 group and this indicator was positively correlated with stocking density (Fig. 1).

The results obtained concerning the other parameters showed significant differences between groups, with the exception of the SGR. The average value of that coefficient ranged from 20.06 to $17.38\left(\% \mathrm{~d}^{-1}\right)$. Group Cc-50 was characterised by the highest coefficient $K$ amongst all the groups, reaching an average value of 1.02 . Between the groups Cc-100, Cc-300 and Cc-500 (0.97, 0.96 and 0.96\% $\mathrm{d}^{-1}$, respectively) no significant differences were found. However, they differed significantly from groups Cc-200, Cc-400 and Cc-600 (0.93, 0.95 and $0.93 \% \mathrm{~d}^{-1}$, respectively), between which no statistical differences were found (Table 2). The larvae from the group Cc-50 were characterised by the most advanced development (in average 6.62), statistically larger than the other groups, with the exception of the Cc-100 group. No statistically significant differences between the other groups were found (the average range was from 6.23 to 6.00) (Table 2). During the experiment, the survival rates of the larvae were high amongst all groups and ranged from 87.5 to $90.0 \%$ (Table 2).

\section{Experiment 2}

The difference in the total lengths of the larvae fed from the beginning of exogenous feeding on different types of feeds was evident by the 7 th day of rearing (Table 3 ). The largest larvae were recorded in groups $\mathrm{AN}$ and $\mathrm{AH}$ ( 8.88 and $8.82 \mathrm{~mm}$, respectively). The average length of the larvae in group DC was much smaller at $7.36 \mathrm{~mm}$, although the individuals in that group were statistically longer than those of the remaining groups (GF, $\mathrm{HF}$ and $\mathrm{PF}$ ), where the larvae reached lengths ranging from 6.52 to 6.87. After week 2 of rearing, the best results were recorded in the group AN, which differed evidently from those in the AH group. The larvae in those groups reached lengths of 12.84 and $11.61 \mathrm{~mm}$, respectively. After 21 days of rearing, the longest individuals were obtained in the AN group (16.55 $\mathrm{mm}$ in average). Statistically smaller larvae were recorded in the AH group 


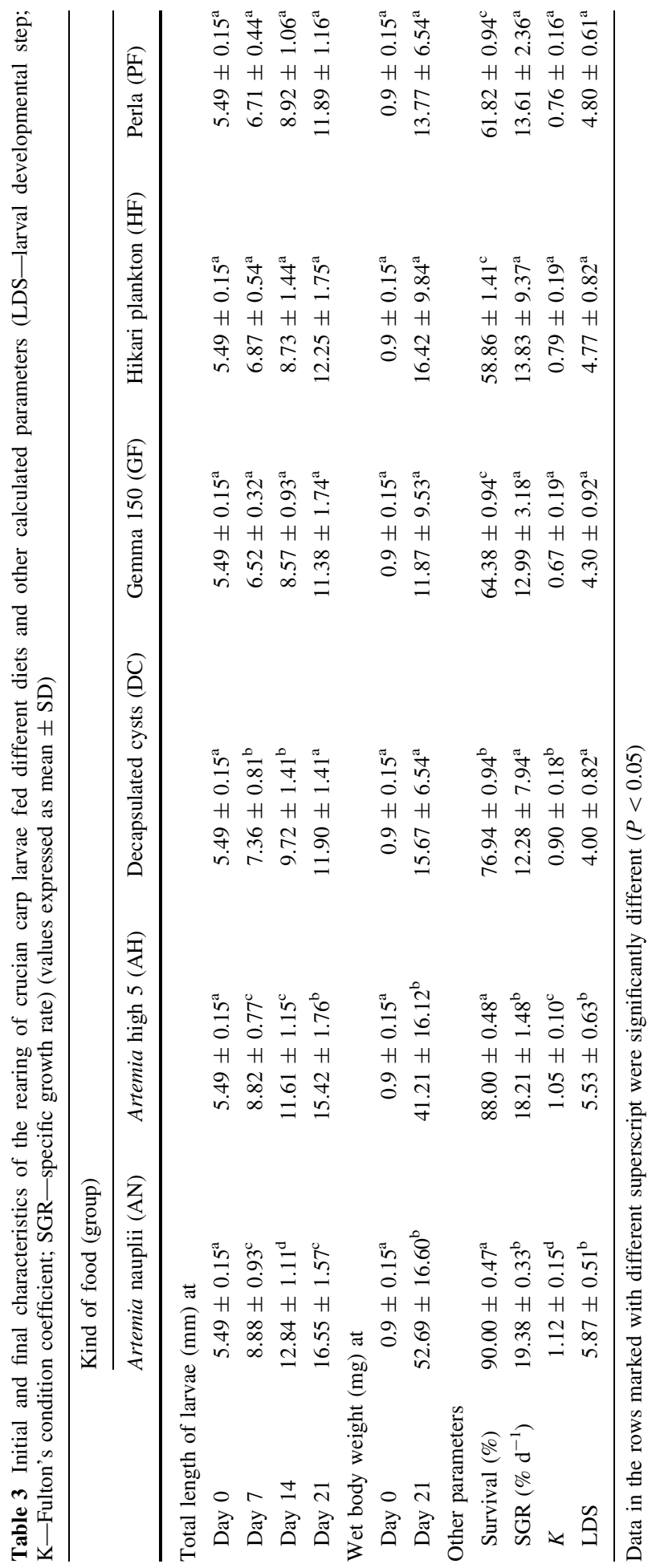




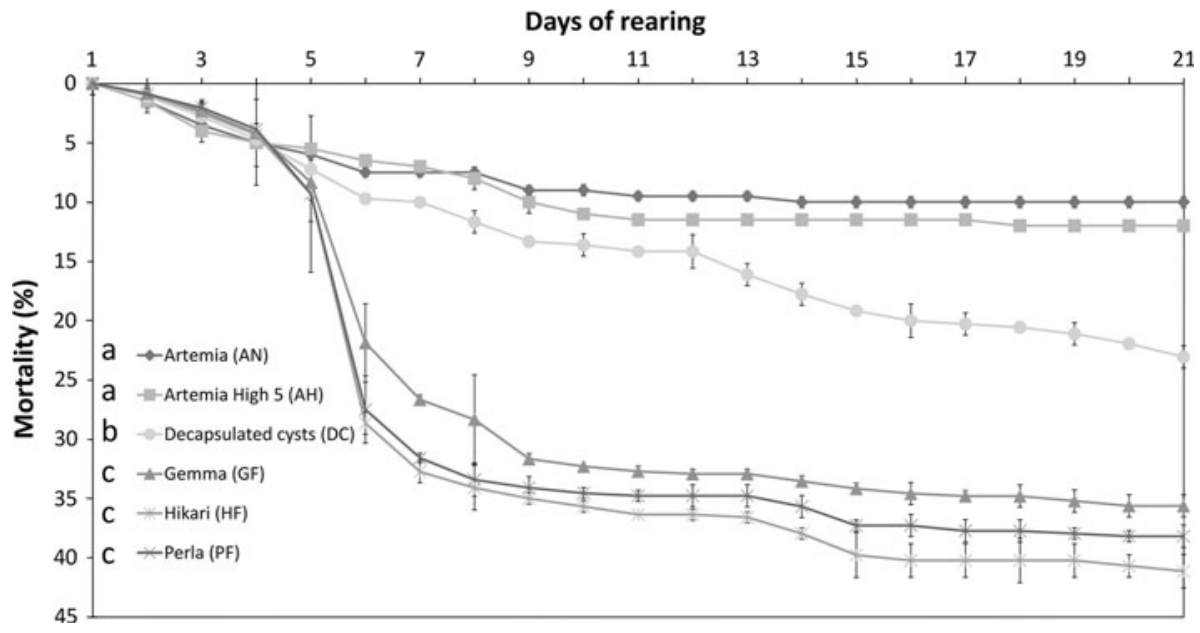

Fig. 2 Cumulative mortality (mean \pm SD) of crucian carp larvae reared with different kinds of food offered. Different letters (marked in the legend) indicate statistical differences between groups $(P<0.05)$

(15.42 $\mathrm{mm}$ in average) which, in turn, were significantly larger than the fish in the remaining groups, between which no statistical differences were recorded. In those groups, the average total length of the larvae ranged from 11.38 to $12.25 \mathrm{~mm}$. The largest average mass of individual larvae at the end of the experiment was recorded in the AN and the AH groups (52.69 and $41.21 \mathrm{mg}$, respectively). No differences were found amongst the other groups, although the larvae in those groups had a significantly lower average mass than the fish in groups $\mathrm{AN}$ and $\mathrm{AH}$, where the average mass of the individuals ranged from 11.87 to $16.42 \mathrm{mg}$ (Table 3).

The highest SGR coefficient, significantly higher than in the remaining groups, was obtained in groups AN and $\mathrm{AH}$ (19.38 and $18.21 \% \mathrm{~d}^{-1}$, respectively) (Table 3 ). On the other hand, the $K$ coefficient was the highest in the AN group (1.12 in average) and it differed statistically from those obtained in the remaining groups, amongst which the lowest values were recorded in groups GF, HF and PF, between which no differences were recorded (Table 3). The best results in developmental stages were obtained in the groups $\mathrm{AN}$ (5.87) and $\mathrm{AH}$ (5.53). The range of values recorded in other groups, which differed significantly from the AN and AH groups, was from 4.00 to 4.80. The highest survival rates of the larvae were recorded in the groups $\mathrm{AN}$ and $\mathrm{AH}$ (90.0 and 88.0\%, respectively). A statistically lower survival rate was obtained in group DC (76.9\%) which, in turn, differed significantly from the remaining groups (Fig. 2).

\section{Discussion}

The initial size of the crucian carp larvae is one of the lowest amongst freshwater cyprinids distributed in Central Europe. The total initial length (at the start of exogenous feeding) of various species such as ide, dace Leuciscus leuciscus (L.), chub or asp ranged between 7.86 and $9.12 \mathrm{~mm}$ and initial body weight ranged from 1.3 to $3.0 \mathrm{mg}$ (Kujawa 2004; Kwiatkowski et al. 2008) and were bigger than crucian carp (5.49 mm of TL and $0.9 \mathrm{mg}$ of wet body weight). A comparable initial size was recorded for common carp Cyprinus carpio (L.) 
(5.3-6.8 mm of TL) (Kucharczyk et al. 2008), goldfish Carassius auratus (L.) (Rema and Gouveia 2005) and rudd (5.7 $\mathrm{mm}$ of TL and $0.9 \mathrm{mg}$ of wet body weight) (Wolnicki et al. 2009). Only tench Tinca tinca (L.) was reported to be smaller (from 4.53 to $4.86 \mathrm{~mm}$ of TL and $0.49 \mathrm{mg}$ of wet body weight) than crucian carp larvae (Quiros and Alvarino 2000). However, the growth rate of crucian carp in this study was one of the highest $\left(\mathrm{SGR}=20.06 \% \mathrm{~d}^{-1}\right.$ in group Cc-50). For example, SGR for chub and ide was equal to 18.05 and $16.21\left(\% \mathrm{~d}^{-1}\right)$, respectively (Kwiatkowski et al. 2008). Kujawa et al. (2010) during rearing of asp and nase recorded SGR 17.06 and $12.14\left(\% \mathrm{~d}^{-1}\right)$, respectively. A similar growth rate to crucian carp was reported for rudd larvae $\left(20.63 \% \mathrm{~d}^{-1}\right)$ (Wolnicki et al. 2009) and goldfish (22.66\% $\mathrm{d}^{-1}$ ) (Rema and Gouveia 2005). In addition, tench larvae reared by Wolnicki et al. (2003) under comparable conditions grew similarly fast $\left(\mathrm{SGR}=19.75 \% \mathrm{~d}^{-1}\right)$.

A negative effect of stocking density on fish growth was reported in many studies. However, the mechanism is not fully known. In most cases, the authors suggest the influence of social interactions, including cannibalism and changes in physicochemical characteristics of the water resulting from an excessively high density applied (e.g. King et al. 2000; Alvarez-Gonzalez et al. 2001; Żarski et al. 2008). Contrary to other authors, Daniels et al. (1996), rearing the larvae of flounder Paralichthys lethostigma (Jordan and Gilbert) under laboratory conditions, showed that an increase in stocking density did not affect the rearing outcome. In consequence, it could be assumed that this might result from the scale of rearing carried out, because in a large-scale experiment it is more difficult to keep the comparable water parameters (e.g. avoid instantaneous elevated ammonia levels or hypoxia zones in rearing tanks shortly after feeding) (King et al. 2000; Kupren et al. 2009). However, in this study, despite maintaining very good and comparable water quality in all treatment groups, significant differences were found. However, significant size differences were found to be density-dependent only at low densities (below 200 ind. $1^{-1}$ ). It is noteworthy that a higher stocking density obtained a significantly larger biomass from the same volume unit, whilst the values of individual parameters did not differ significantly between the groups using 200 larvae per litre or more (Fig. 1). The larvae in those groups were also similar in developmental advancement, as well as in condition coefficient $(K)$. However, the growth rate (SGR) was at the same level in all experimental treatments (from 50 to 600 ind. $1^{-1}$ ). A similar correlation was also observed by Kupren et al. (2009) in the rearing of dace in high densities. Also, in the case of goldfish larvae, a negative effect of density was observed in the lowest density (20 ind. $1^{-1}$ ) as compared to other treatments (within the range 50-80 ind. $1^{-1}$ ) (Rema and Gouveia 2005).

In view of these studies, it could be concluded that the effect of density may be directly linked to fish size and their developmental advancement (Irwin et al. 1999; Ambrosio et al. 2008). It could be suggested that fish which are much more advanced ontogenetically are able to react more intensively to stimuli around them. This may have directly affected physiological factors resulting from stress (Costas et al. 2008) and consequently reduced growth rate. Thus, the lack of differences in crucian carp larvae growth in high stocking densities (above 200 ind. $1^{-1}$ ) could be linked to small initial size and developmental advancement and that larvae (in such high densities) were exposed to the maximum stimuli to which they could react. Thus, in crucian carp larvae, the negative density-dependent effect did not occur at high densities. This phenomenon became more noticeable during the ontogenetic development. Up to day 7, less ontogenetically advanced larvae were less able to experience the stimuli, due to the high stocking density to which they were exposed. 
The size differentiation between the groups with the lowest stocking densities (from 50 to 200 ind. $1^{-1}$ ) and the highest (from 200 to 600 ind. $1^{-1}$ ) increased during the rearing period. It is noteworthy that this is the first report on the successful application of such high stocking densities in cyprinid larviculture.

The application of dry feed as the sole food for crucian carp resulted in a decrease in all of the analysed indicators compared to the group fed only with Artemia. Attention should be paid to the fact that none of the commercial feeds chosen for the experiments matched the natural feed, which is particularly well reflected in the survival rates of the larvae. The highest mortality in groups in which larvae were fed commercial diets was highest in the period of about 4-8 days. This is clearly visible in the shape of the curves plotted in Fig. 2 for those groups. It could be suggested that the mortality of larvae, which were not eating, occurred during this period. The shape of the curves in the remaining groups was characteristic for the dynamic of mortality in cyprinid larviculture (Kwiatkowski et al. 2008; Żarski et al. 2008; Kujawa et al. 2010). For larvae that were fed with decapsulated cysts, it was higher at the end of the rearing period when compared with the remaining groups. It was previously reported that stability in the water of decapsulated cysts of Artemia is much higher than compound feed pellets (Ribeiro and Jones 1998). The cysts are also very energetic and much more digestible than compound feeds (Leger et al. 1986; Pector et al. 1994; Shiri Harzevili et al. 2003). Crucian carp larvae probably assimilated some of the nutritional substances, however, not enough to cover their requirements. Thus, relatively delayed mortality rate was observed.

Decapsulated Artemia cysts were applied successfully as the first feed during rearing of ide (Shiri Harzevili et al. 2004), chub (Shiri Harzevili et al. 2003) and carp (Vanhaecke et al. 1990). Common carp, goldfish and rudd larvae, which are comparable in size to crucian carp, were successfully reared with commercial feeds as a sole food already (AbiAyad and Kestemont 1994; Carvalho et al. 1997; Wolnicki et al. 2009). In this study, larvae fed only with dry food were less advanced in development and had much lower Fulton's condition coefficient compared to the control group. A similar sensitivity was observed in common tench larvae (Wolnicki and Górny 1995); however, recent data indicate that it is possible to successfully rear larvae of common tench with dry food without a negative effect on their survival (Mamcarz et al. 2011). Thus, the obtained results suggest that crucian carp is very sensitive amongst cyprinids to the type of food offered at the start of exogenous feeding. This is most probably correlated with the poorly developed alimentary system of the larvae of that species (Dabrowski 1984b). As the rearing of juvenile forms can be carried out successfully applying compound feeds (Myszkowski et al. 2002), it is necessary to determine the optimum conditions for the transition from natural food to dry feed.

The obtained results could be very useful in potential controlled rearing of crucian carp larvae. In addition, the data presented also further advance a better understanding of the cyprinid fish species and may have a great influence on crucian carp fry production. This regards both commercial utilisation and sustainable activities directed at maintaining the biodiversity of natural environments through restocking activities. It should be assumed that further studies into the rearing of crucian carp larvae are needed to optimise conditions for effective production of this species.

Open Access This article is distributed under the terms of the Creative Commons Attribution Noncommercial License which permits any noncommercial use, distribution, and reproduction in any medium, provided the original author(s) and source are credited. 


\section{References}

Abi-Ayad A, Kestemont P (1994) Comparison of the nutritional status of goldfish (Carassius auratus) larvae fed with live, mixed or dry diet. Aquaculture 128:163-176

Alvarez-Gonzalez C, Ortiz-Galindo JL, Dumas S, Martinez-Diaz S, Hernandez-Ceballos DE, Grayeb-Del Alamo T, Moreno-Legoretta M, Pena-Martinez R, Civera-Cerecedo R (2001) Effect of stocking density on the growth and survival spotted sand bass Paralabrax maculatofasciatus larvae in a closed re-circulating system. J World Aquacult Soc 32:130-137

Ambrosio PP, Costa C, Sánchez P, Flos R (2008) Stocking density and its influence on shape of Senegalese sole adults. Aquacult Int 16:333-343

Carvalho AP, Escaffre A-M, Oliva Teles A, Bergot P (1997) First feeding of common carp larvae on diets with high levels of protein hydrolysates. Aquacult Int 5:361-367

Copp GH, Cerný J, Kováč V (2008) Growth and morphology of an endangered native freshwater fish, crucian carp Carassius carassius, in an English ornamental pond. Aquat Cons Mar Freshw Eco $18: 32-43$

Costas B, Aragao C, Mancera JM, Dinis MT, Conceicao LEC (2008) High stocking density induces crowding stress and affects amino acid metabolism in Senegalese sole Solea senegalensis (Kaup 1858) juveniles. Aquacult Res 39:1-9

Cowx IG (1994) Stocking strategies. Fish Manage Ecol 1:15-30

Dạbrowski K (1984a) Influence of initial weight during the change from live compound feed on the survival and growth of four cyprinids. Aquaculture 40:27-40

Dąbrowski K (1984b) The feeding of fish larvae, present „state of the art” and perspectives. Reprod Nutr Dev 24:807-833

Daniels HV, Berlinsky DL, Hodson RG, Sullivan CV (1996) Effects of stocking density, salinity, and light intensity on growth and survival of southern flounder Paralichthys lethostigma larvae. J World Aquacult Soc 27:153-159

FAO (2004) Carassius carassius cultured aquatic species information programme text by Weimin M. In: FAO Fisheries and Aquaculture Department [online], Rome. (http://wwwfaoorg/fishery/ culturedspecies/Carassius_carassius/en)

Fréchette M (2005) A comment on the methodology of stocking experiments. Aquaculture 250:291-299

Hakuć-Błażowska A, Kupren K, Turkowski K, Targońska K, Jamróz M, Krejszeff S, Kwiatkowski M, Żarski D, Kucharczyk D (2009) Comparison of economic effectiveness of applying different hormonal preparations for reophile cyprinid fish reproduction stimulation based on the example of asp Aspius aspius (L) and ide Leuciscus idus (L). Pol J Nat Sci 24:224-234

Hamáčková J, Prokeš M, Kozák P, Peňáz M, Stanny LA, Policar T, Baruš V (2009) Growth and development of vimba bream (Vimba vimba) larvae in relation to feeding duration with live and/or dry starter feed. Aquaculture 287:158-162

Holopainen IJ, Aho J, Vornanen M, Huuskonen H (1997) Phenotypic plasticity and predator effects on morphology and physiology of crucian carp in nature and in the laboratory. J Fish Biol 50:781-798

Horvath L, Szabo T, Burke J (1997) Hatchery testing of GnRH analogue containing pellets on ovulation in four cyprinid species. Pol Arch Hydrobiol 44:281-292

Irwin S, O'Halloran J, FitzGerald RD (1999) Stocking density, growth and growth variation in juvenile turbot, Scophthalmus maximus (Rafinesque). Aquaculture 178:77-88

Jørgensen EH, Jobling M (1993) Feeding in darkness eliminates density-dependent growth suppression in Arctic charr. Aquacult Int 1:90-93

King NJ, Howell WH, Huber M, Bengtson DA (2000) Effects of larval stocking density on laboratory-scale and commercial-scale production of summer flounder Paraliehthys dentatus. J World Aquacult Soc 31:436-445

Krejszeff S, Żarski D, Kucharczyk D, Kupren K, Targońska K, Mamcarz A (2010) An experimental device for egg incubation and fish larvae rearing under laboratory conditions. Pol J Nat Sc 25:190-199

Kucharczyk D, Targońska K, Hliwa P, Gomułka P, Kwiatkowski M, Krejszeff S, Perkowski J (2008) Reproductive parameters of common carp (Cyprinus carpio L) spawners during natural season and out-of-season spawning. Reprod Biol 8:285-289

Kujawa RJ (2004) Biologiczne podstawy podchowu larw reofilnych ryb karpiowatych w warunkach kontrolowanych. Rozprawy i monografie, 88, Wyd UWM, Olsztyn, p 88

Kujawa R, Kucharczyk D, Mamcarz A (1999) A model system for keeping spawners of wild and domestic fish before artificial spawning. Aquacult Eng 20:85-89

Kujawa R, Kucharczyk D, Mamcarz A, Jamróz M, Kwiatkowski M, Targońska K, Żarski D (2010) Impact of supplementing natural feed with dry diets on the growth and survival of larval asp, Aspius aspius (L), and nase, Chondrostoma nasus (L). Arch Pol Fish 18:13-23 
Kupren K, Turkowski K, Kucharczyk D, Krejszeff S, Żarski D, Hakuć-Błażowska A, Targońska K, Kwiatkowski M, Jamróz M, Czarkowski T (2008) Economic aspects of rearing larval asp, Aspius aspius (L), and ide, Leuciscus idus (L) in closed re-circulating systems. Arch Pol Fish 16:413-420

Kupren K, Żarski D, Krejszeff S, Kucharczyk D, Targońska K, Mamcarz A (2009) The influence of stocking density on survival and growth of dace Leuciscus leuciscus (L) larvae reared under laboratory conditions. Eur Aquacult Soc Spec Publ 38:217-220

Kwiatkowski M, Żarski D, Kucharczyk D, Kupren K, Jamróz M, Targońska K, Krejszeff S, HakućBłażowska A, Kujawa R, Mamcarz A (2008) Influence of feeding chosen rheophilic cyprinid larvae using natural and compound diet. Arch Pol Fish 16:383-396

Leger P, Bengtson DA, Simpson KL, Sorgeloos P (1986) The use and nutritional value of Artemia: as food source. Oceanogr Mar Biol Ann Rev 24:521-623

Mamcarz A, Targońska K, Kucharczyk D, Kujawa R, Żarski D (2011) The effect of live and dry food on rearing of tench (Tinca tinca L.) larvae under controlled conditions. Ital J Anim Sci (in press)

Myszkowski L, Kamiński R, Quiros M, Stanny LA, Wolnicki J (2002) Dry diet-influenced growth, size variability, condition and body deformities in juvenile crucian carp Carassius carassius $\mathrm{L}$ reared under controlled conditions. Arch Pol Fish 10:51-61

Pector R, Tackaert W, Abelin P, Ollevier F, Sorgeloos P (1994) A comparative study on the use of different preparations of decapsulated Artemia cysts as food for rearing catfish, Clarias gariepinus (L) larvae. J World Aquacult Soc 25:366-370

Peňaz M, Prokeš M, Kouřil J, Hamackowa J (1983) Early development of the carp, Cyprinus carpio. Acta Sc Nat Brno 17:1-39

Quiros M, Alvarino JMR (2000) Growth and survival of tench larvae fed under different feeding strategies. J Appl Ichthyol 16:32-35

Rema P, Gouveia A (2005) Growth and survival of goldfish (Carassius auratus) larvae reared at different stocking densities. J Anim Vet Adv 4:274-275

Ribeiro FALT, Jones DA (1998) The potential of dried, low hatch, decapsulated Artemia cysts for feeding prawn post-larvae. Aquacult Int 6:421-440

Ross LG, Martinez Palacios CA, Morales EJ (2008) Developing native fish species for aquaculture, the interacting demands of biodiversity, sustainable aquaculture and livelihoods. Aquacult Res 39:675-683

Sarkar UK, Deepak PK, Negi RS, Singh S, Kapoor D (2006) Captive breeding of endangered fish Chitala chitala (Hamilton-Buchanan) for species conservation and sustainable utilization. Biodiv Conserv 15:3579-3589

Shiri Harzevili A, De Charleroy D, Auwerx J, Vught I, Van Slycken J (2003) Larval rearing of chub, Leuciscus cephalus (L), using decapsulated Artemia as direct food. J Appl Ichthyol 19:123-125

Shiri Harzevili A, Vught I, Auwerx J, De Charleroy D (2004) Larval rearing of ide (Leuciscus idus (L)), using decapsulated Artemia. Arch Pol Fish 12:191-195

Skrzypczak A, Mamcarz A (2005) Crucian carp, Carassius carassius (L), in the fishery exploited lakes of north-eastern Poland in 1951-1994. Acta Sci Pol Piscaria 4:89-100

Targońska K, Żarski D, Krejszeff S, Kucharczyk D (2009) Artificial reproduction of crucian carp, Carassius carassius (L) - preliminary results. Aquaculture Europe 2009. Trondheim, Norway, pp 602-603

Tarkan AS, Copp GH, Zięba G, Godart MJ, Cucherousset J (2009) Growth and reproduction of threatened native crucian carp Carassius carassius in small ponds of Epping Forest, south-east England. Aquat Cons: Mar Fresh Ecosyst 19:797-805

Vanhaecke P, De Vrieze L, Tackaert W, Sorgeloos P (1990) The use of decapsulated cysts of the brine shrimp Artemia as direct food for carp Cyprinus carpio L larvae. J World Aquacult Soc 21:257-262

Wolnicki J (2005) Intensywny podchów wczesnych stadiów ryb karpiowatych w warunkach kontrolowanych. Arch Pol Fish 13:5-87

Wolnicki J, Górny W (1995) Controlled rearing of ide (Leuciscus idus L) larvae using live food and dry feed. Aquaculture 129:255-256

Wolnicki J, Kamiński R, Myszkowski L (2003) Survival, growth and condition of tench Tinca tinca (L) larvae fed live food for 12,18 or $24 \mathrm{~h}$ a day under controlled conditions. J Appl Ichthyol 19:146-148

Wolnicki J, Sikorska J, Kamiński R (2009) Response of larval and juvenile rudd Scardinius erythrophthalmus (L) to different diets under controlled conditions. Czech J Anim Sci 54:331-337

Żarski D, Kucharczyk D, Kwiatkowski M, Targońska K, Kupren K, Krejszeff S, Jamróz M, HakućBłażowska A, Kujawa R, Mamcarz A (2008) The effect of stocking density on the growth and survival of larval asp Aspius aspius (L) and European chub Leuciscus cephalus (L) during rearing under controlled conditions. Arch Pol Fish 16:371-381 